\title{
Analisis Pencatatan Premi Dan Recovery Klaim Pada PT. Asuransi Purna Arthanugraha Cabang Pekanbaru
}

\author{
PRAMA WIDAYAT \\ Dosen Tetap Fakultas Ekonomi Universitas Lancang Kuning \\ Jln. Yos Sudarso KM 8 Rumbai \\ E-mail : pramawidayat@yahoo.com
}

\begin{abstract}
This study aims to analyze how the recording of premium received by the company and how the process of claim recovery has been done. The method used in this study is to retrieve secondary data of the company from 2012 to 2016, by looking at premium receipts and claims recovery for 5 years (2012-2016). The results showed that the recording of premium received for 5 years tends to rise, while the claim recovey process is still experiencing obstacles and need special steps in handling. This is as a result of the moral hazard of the customer or the insured who escaped the obligation.
\end{abstract}

Keywords: Premium Record and Recovery Claims

Asuransi merupakan sarana keuangan dalam tata kehidupan rumah tangga, baik dalam menghadapi risiko atas harta benda yang dimiliki. Demikian pula dunia usaha dalam menjalankan kegiatannya menghadapi risiko yang mungkin dapat mengganggu kesinambungan usahanya.Walaupun banyak metode untuk menangani risiko, namun asuransi merupakan metode yang paling banyak dipakai.

Berjalannya waktu dan kesadaran diri masyarakat akan pentingnya perlindungan akan potensi risiko yang akan dihadapi dimasa mendatang. Namun muncul permasalahan ketika seorang nasabah sudah diberikan polis asuransi seperti polis asuransi kebakaran atau asuransi kendaraan, untuk polis dengan jangka waktu 1 tahun maka diberikan jangka waktu pembayaran selama 14 hari kalender sedangkan untuk polis dibawah 1 tahun maka ketika polis terbit langsung dibayar cash. Jangka waktu ini sering terabaikan dan bahkan bisa melebihi 30 hari kalender dengan berbagai macam alasan.

Kemudian untuk polis jaminan seperti jaminan penawaran, jaminan pelaksanaan, jaminan uang muka dan jaminan pemeliharaan baik berupa Kontra
Garansi Bank (KGB) maupun Surety Bond. Dimana untuk Kontra Garansi Bank (KGB) berupa jaminan dari asuransi $90 \%$ dan dari bank $10 \%$. Sedangkan untuk surety bond jaminan $100 \%$ oleh asuransi. Kontra Garansi Bank (KGB) maupun surety bond sama - sama cash and carry dan tidak boleh ada tunggakan premi, tetapi dalam prakteknya sering terjadi pelanggaran dan pembayaran premi melebihi dari 30 hari dan akhirnya menimbulkan outstanding premi.

Masalah akan timbul jika kemudian hari jaminan KGB atau surety bond terjadi wanprestasi atau gagal melaksanakan kewajiban, dimana kontraktor (principle) mengalami kendala dalam melaksanakan proyek yang dijamin oleh bank ataupun asuransi. Jika waktu pekerjaan tidak selesai maka pemilik proyek (obligee) dalam hal ini pemerintah daerah atau pemerintah provinsi akan meminta pencairan jaminan tanpa syarat dalam waktu 14 (empat belas) hari kerja langsung ke rekening pemda atau pemprov. Pihak Bank atau asuransi wajib membayar kepada obligee dan setelah itu pihak asuransi akan menagih ulang kepada principle. 
Karena jaminan ini sifatnya hanya menalangi sementara dan berbeda dengan klaim, yang namanya jaminan hanya sebatas pihak penjamin bukan mengganti kerugian pihak principle atau oblige. Hal ini kebanyakan tidak dipahami oleh principle karena mereka menganggap ketika sudah dibayar oleh pihak asuransi maka segala kewajiban mereka gugur. Hal inilah yang menyulitkan pihak asuransi untuk menagih (recovery) atas pencairan jaminan, sejak tahun 2012 - 2015 tercatat lebih dari Rp 3 Milyar recovery yang belum kembali ke kas ASPAN. Upaya persuasif sudah dilakukan namun masih belum tercapai, hingga pertengahan tahun 2016 baru $10 \%$ recovery yang diterima oleh ASPAN. Jika diambil rata-rata per tahun Rp 1 Milyar jumlah recovery jaminan.

Jumlah pendapatan premi selama 1 tahun rata-rata $\mathrm{Rp} 2$ Milyar, jika nasabah tidak membayar premi kepada perusahaan sangat berdampak pada perusahaan, karena premi adalah pendapatan perusahan. penagihan recovery klaim di PT.Asuransi Purna Artanugraha sudah cukup berjalan dengan baik, meskipun penagihan recovery klaim dan penagihan premi masih susah, sehingga berpengaruh pada pendapatan perusahaan PT. Asuransi Purna Artanugraha. Permasalahan yang terjadi pada premi adalah lamanya pembayaran dari nasabah yang sangat berpengaruh pada pendapatan premi pada perusahaan serta recovery klaim yang belum maksimal.

Asuransi kerugian adalah suatu perjanjian dengan satu pihak penanggung terhadap pihak yang tertanggung untuk menggantikan kerugian yang dapat diderita oleh tertanggung, karena terjadinya suatu peristiwa yang telah ditunjuk dan yang belum tentu secara kebetulan, dengan mana pula tertanggunng berjanji untuk membayar premi Molengraaf Pada Djojosoedarso (2000). Sesuai dengan UUD RI No. 40 Tahun 2004 bahwa industri perasuransian yang sehat, dapat di andalkan, amanah, dan kompetitif akan meningkatkan perlindungan bagi pemegang polis, tertanggung atau peserta, dan berperan mendorong pembangunan nasional;

Perusahaan asuransi adalah perusahaan yang bergerak dibidang jasa pertanggungan atas risiko atau kerugian yang di alami oleh tertanggung atas risiko atau kerugian yang dialami oleh tertanggung. Perkembangan perusahaanperusahaan asuransi di luar negeri dapat di katakan sudah sangat baik karena asuransi sudah dianggap sebagai gaya hidup masyarakat dari kalangan bawah maupun kalangan atas, sedangkan di indonesia asuransi masih dianggap sesuatu yang mewah karena sebagian besar pemakaian jasa asuransi adalah kalangan atas.

Pernyataan standar akuntansi keuangan (PSAK) No. 28 (2004:28.3) dalam standar akuntansi keuangan merupakan standar acuan akuntansi asuransi kerugian. Pada hakekatnya adalah suatu sistem preteksi menghadapi risiko kerugian financial dengan cara mengalihkan (Transfer) risiko kepada pihak lain, baik secara perorangan maupun secara kelompok dalam masyarakat. Digolongkan ke dalam asuransi kerugian antara lain asuransi kebakaran, Asuransi Pengangkutan, Asuransi Kendaraan Bermotor, Asuransi Rangka Kapal Laut, Asuransi Rangkah Kapal Udara, Asuransi Pengiriman dan Penyimpanan Surat Berharga, dan lainlain.

Kegiatan Operasional Pokok perusahaan asuransi tidak lepas dari premi yaitu pembayaran oleh nasabah dan klaim yaitu pertanggungan yang harus diberikan oleh perusahaan asuransi. Klaim adalah ganti rugi yang di bayarkan atau yang menjadi kewajiban kepada tertanggung atau perusahaan asuransi (cending company) sehubungan dengan telah terjadinya kerugian. Bagian klaim yang di terima dari reasuradur merupakan salah satu bentuk " pemulihan klaim" (claim recovery). Beban klaim di akui dan di catat bersama dengan timbulnya kewajiban kepada tertanggung perusahaan 
asuransi (cending company) yaitu pada periode tercapainya persetujuan ganti rugi kepada tertanggung.

Pengertian Premi menurut Abdulkadir Muuhammad (2011:103) dapat diketahui bahwa premi adalah salah satu unsur penting dalam asuransi karena merupakan kewajiban pokok yang wajib dipenuhi oleh tertanggung kepada penanggung. Premi bruto adalah premi yang di peroleh dari tertanggung ,agen,broker maupun dari perusahaan asuransi lain dan perusahaan reasuransi. Premi bruto yang berasal pertanggungan langsung (direct business) dinamakan premi langsung. Sedangkan premi yang berasal dari pertanggungan tidak langsung ( direct business ), yaitu yang diterima dari perusahaan asuransi lain atau perusahaan reasuransi dinamakan premi tidak langsung - premi yang diperoleh diakui sebagai pendapat berdasarkan accrual basis yang dialokasikan secara merata selama masa pertanggungan. Pendapatan koasuransio diakui sebesar pangsa (share) premi yang akan diterima oleh perusahaan.

Menurut Soeisno Djojosoedarso (2003:127) mengemukakan premi asuransi sebagai pembayaran dari tertanggung kepada penanggung, sebagai imbalan jasa atas pengalihan risikon para penanggung. Dengan demikian premi asuransi akan merupakan:

a. Imbalan jasa atas jaminan yang diberikan oleh penanggung kepada tertranggung untuk menggantikan kerugian yang mungkin diderita oleh tertanggung (pada asuransi kerugian).

b. Imbalan jasa atas jaminan yang diberikan oleh penanggung kepada tertranggung dengan menyediakan sejumlah uang (benefit) terhadap resiko yang akan terjadi. Premi asuransi merupakan sejumlah uang yang sudah disepakati atau ditetapkan dari pihak perusahaan asuransi dan harus dibayar setiap bulannya sebagai kewajiban dari tertanggung atas keikutsertaannya dengan cara tertentu.
Dalam kamus besar bahasa Indonesia, klaim adalah tuntutan atas suatu fakta bahwah seorang berhak (untuk memiliki atau mempunyai atas sesuatu. Menurut kamus umum bahasa Indonesia, klaim adalah tuntutan atas sesuatu yang dianggapmenjadi hak.

Dalam kamus asuransi, klaim berarti permohonan atau tuntutan pemilik polis terhadap perusahaan asuransi untuk pembayaran santunan sesuai dengan pasal-pasal dari sebuah polis.Klaim juga berarti aplikasi oleh peserta untuk memperoleh pertanggungan atas kerugiannya yang tersedia berdasarkan perjanjian.

Klaim merupakan perkejadian tersebut berdasarkan ketentuan polis.sedangkan klaim adalah proses yang mana peserta dapat memperoleh hak-hak berdasarkan perjanjian tersebut. Tidak ada alasan bagi perusahaan asuransi untuk memperlambat pembayaran klaim kepada tertanggung karena 1;aim adalah suatu proses yang telah di antisipasi sejak awal oleh semua perusahaan asuransi.

Definisi klaim yang terdapat dalam PSAK No. 28 (2004:28.3) tentang perusahaan asuransi kerugian yaitu sebagai berikut : "Klaim bruto adalah klaim yang jumlahnya telah disepakati, termasuk biaya penyelesaian klaim.”.

Pada masalah klaim, yang harus dilakukan adalah establish cause of loss mencari penyebaab yang sebenarnya dari kerugian. Untuk mencari penyebab dari kerugian ini, metode yang digunakan adalah :Proximate cause, Insurable interest, Indemnity.

Dengan perkataan lain Proximate cause, Insurable interest, dan indemnity merupakan filter atau saringan untuk pengeluaran premi dari fund di dalam pembayaran klaim, sehingga dapat disimpulkan bahwa klaim merupakan puncak dari asuransi.

Kemampuan perusahaan dalam memenuhi semua kewajiban jangka pendeknyadapat dilihat dari rasio likuiditas yang dicapai perusahaan. 


\section{METODE}

Penelitian menggunakan metode deskriptif, berusaha menganalisa pencatatan premi dan recovery klaim yang ada di PT. Asuransi Purna Arthanugraha sejak tahun 2012-2016. Dilihat dari jumlah penerimaan premi dan jumlah recovery klaim yang bisa ditarik dari priciple (kontraktor)

Pengumpulam data menggunakan metode wawancara dengan kepala cabang dan dokumentasi yang bersumber dari data PT. Asuransi Purna Arthanugraha Cabang Pekanbaru, dengan menggunakan data perusahaan sejak tahun 2012-2016 berupa data pencatatan premi dan recovery klaim yang telah dilaksanakan.

Data yang diperoleh dari survey maupun dokumentasi, dilakukan analisis dengan metode deskriptif.

\section{HASIL}

Terjadi peningkatan yang cukup signifikan dalam pencatatan atau penerimaan premi dari tahun 2012 hingga 2016. Dalam waktu 5 (lima) tahun terjadi peningkat $80 \%$ (delapan puluh persen). Untuk tahun 2012 tidak menerima pendapatan premi dari produk Marine Cargo (pengangkutan) dan personal accident. Tahun 2013 tidak ada penerimaan premi dari produk personal accident dan lain-lain. Tahun 2014 juga tidak ada penerimaan dari produk personal accident dan lain-lain. Tahun 2015 pada produk marine cargo kembali tidak mendapatkan premi padahal tahun 2013 dan 2014 terdapat penerimaan premi. Tahun 2016 semua produk yang dimiliki oleh ASPAN menerima premi karena memang perusahan semakin berkembang dan kepercayaan nasabah semakin tumbuh untuk memiliki asuransi dari ASPAN.

Tabel 1. Penerimaan Premi Berdasarkan Bisnis Tahun 2012-2016

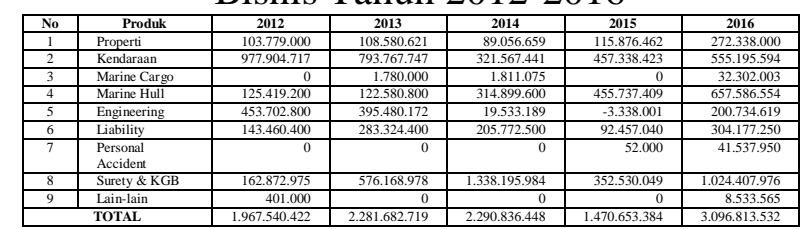

Sumber : Aspan Pekanbaru
Kemudian untuk melihat perkembangan recovery klaim sejak tahun 2012-2016 dapat dilihat pada tabel 2 dibawah ini :

Tabel 2. Perbandingan Klaim \& Recovery Klaim Surety dan KGB Tahun 2012-2016

\begin{tabular}{|c|c|c|c|c|}
\hline No & Tahun & Jumlah Klaim & Recovery Klaim & Persentase \\
\hline 1 & 2012 & 237.364 .755 & - & $0 \%$ \\
\hline 2 & 20 & 94.220 .300 & 794.220 .300 & $100 \%$ \\
\hline 3 & 2014 & 1.242 .692 .334 & 879.509 .959 & $70,77 \%$ \\
\hline 4 & 2015 & 1.423 .462 .205 & 841.973 .055 & $59,14 \%$ \\
\hline 5 & 2016 & 210.201 .750 & 62.216 .850 & $29,60 \%$ \\
\hline \multicolumn{2}{|c|}{ TOTAL } & 3.907 .941 .344 & 2.577 .920 .164 & $65,97 \%$ \\
\hline
\end{tabular}

Dari tabel 2 dapat dilihat bahwa perbandingan jumlah klaim dan recovery klaim yang diperoleh pada tahun 2012 tidak ada karena belum ada pengembalian dari kontraktor (obligee). Pada tahun 2013 Aspan bisa menarik 100\% jumlah klaimnya dan ini pencapaian terbaik sejak perusahaan ini berdiri dipekanbaru sejak tahun 2010 . Pada tahun 2014 pencapaian recovery klaim masih cukup baik berkisar di angka $70,77 \%$. Kemudian tahun 2015 terjadi penurunan recovery klaim yaitu sebesar $59,14 \%$ dan ini semakin menurun pada tahun 2016 yang hanya sebesar 29,60\% karena kontraktor tersebut mengalami kesulitan keuangan. Secara keseluruhan bahwa Aspan sanggung menarik recoveri klaim sebesar Rp 2.577.920.164 atau sebesar $65,97 \%$ dari total klaim bank garansi/surety bond sebesar $\mathrm{Rp}$ 3.907.941.344.

\section{PEMBAHASAN}

\section{Pencatatan premi}

Pencatatan premi memang meningkat tetapi tidak merata pada 9 (sembilan) produk yang ada, hanya pada tahun 2016 setiap produk mendapatkan premi tetapi tahun 2012-2015 selalu tidak seimbang. Hal ini disebabkan karena keterbatasan tenaga marketing, marketing yang ada belum memahami semua produk dan persaingan dengan perusahaan asuransi yang sudah mapan.

Walaupun jumlah premi yang didapat cenderung meningkat tetapi tidak 
merata pada semua produk, hal ini disebabkan juga karena kekurangan tenaga marketing, marketing yang ada belum maksimal memahami semua produk sehingga cenderung menjual produk yang pada umumnya diketahui seperti asuransi property dan kendaraan padahal produk lain juga sangat kompetitif jika ditawarkan kepada pasar, serta persaingan dengan lebih kurang 70 (tujuh puluh) perusahaan asuransi yang ada di Pekanbaru menyebabkan sebuah perusahaan memiliki produk unggulan masing-masing. Sementara aspan masih dalam tahap membangun image pasar.

Hal ini didukung dengan wawancara pada hari senin 8 Mei 2017 bersama Bapak Erix Kurniawan selaku kepala cabang ASPAN Pekanbaru bahwa peningkatan premi ini didapat karena kemampuan cabang membaca dan menangkap peluang pasar yang ada didepan mata, tetap mengedepankan langkah hati-hati sebelum menerbitkan jaminan polis. Kita ketahui bahwa kebutuhun jaminan Kontra Garansi Bank yang cukup tinggi karena riau termasuk provinsi yang sedang dalam tahap pembangunan sehingga banyak proyek yang dikerjakan otomatis membutuhkan jaminan tersebut. Maka dari itu peneriman premi dari sektor jaminan Kontra Garansi Bank (KGB) cukup tinggi dari tahun ke tahun.

\section{Recovery klaim}

Sementara itu jumlah klaim semakin meningkat dan recovery klaim juga tidak maksimal dilakukan karena keterbatasan akses kepada kontraktor yang melarikan diri dari tanggung jawab. Padahal perusahaan sangat membutuhkan pengembalian klaim (recovery klaim) tersebut untuk menjadi kas perusahaan karena klaim untuk bank garansi/surety bond ini sifatnya hanya menalangi sementara dan bukan mengganti kerugian kontraktor.

Wawancara kami dengan bapak Erix Kurniawan menjelaskan bahwa recovery klaim ini banyak bermasalah pada tahun 2012-2015 sebelum beliau masuk, ketika itu perusahaan terlalu longgar dalam menerbitkan polis KGB tanpa dokumen yang lengkap. Hal ini dilakukan kepala cabang sebelumnya dengan tujuan mencapai target tanpa mempertimbangkan aspek keamanan, semua dimudahkan dengan cara murahan sehingga pada akhirnya terjadi klaim karena kontraktor yang dijamin tersebut, tidak melaksanakan kewajibannya untuk menyelesaikan pekerjaan.

Selain itu bagian klaim yang kami temui juga memberikan keterangan bahwa rata-rata yang bermasalah adalah nasabah baru yang sebelumnya belum pernah membuat jaminan di ASPAN. Selain itu nasabah yang berasal dari luar Provinsi Riau karena sistem lelang elektronik ini memungkinkan perusahaan diluar daerah riau juga mengikuti lelang di Riau. Kemudian Pinjam meminjam perusahaan karena hubungan teman sehingga meminjamkan perusahaan untuk ikut lelang, ketika terjadi wan prestasi maka akan saling lempar tanggung jawab.

Untuk perusahaan yang berada diluar provinsi riau seperti sumatera barat dan sumatera utara diberikan akses untuk menerbitkan polis dan bahwa mereka menerima uang muka pekerjaan, kemudian melarikan diri dari tanggung jawab pekerjaan. Untuk menagih recovery akan susah karena perusahaan diluar provinsi dan juga tidak memiliki kantor tetap alias tutup karena sewa tempat sudah berakhir.

\section{SIMPULAN}

Simpulan yang diambil adalah pencatatan premi yang diterima selama 5 tahun cenderung naik, sedangkan proses recovey klaim masih mengalami kendala dan perlu langkah-langkah khusus dalam penanganannya. Hal ini sebagai akibat dari moral hazard dari nasabah atau tertanggung yang lari dari kewajiban.

\section{DAFTAR RUJUKAN}

American Accounting Association (AAA)

Bambang Riyanto Mengatakan Dalam Buku Dasar-Dasar Pembelajaran 
Perusahaan, Edisi 4. BPFE, Mulyadi. 2001. Sistem Akuntansi. Jakarta: Yogyakarta (1997:25)

Salemba EmpatMenurut

Bondar, George Hdan William S. Hapwood. 2004. Sistem Informasi Akuntansi Edisi Sembilan, Yogyakarta :Andi

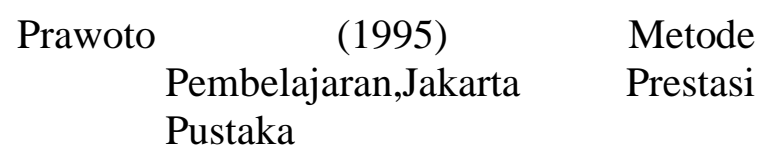

Djojosoedarso, Soeino.2000:74

Sugiyono, 2010, Statistika untuk penelitian, https://anisahaseena.wordpress.com/ $\underline{2014 / 10 / 10 / 469 /}$

George H. Bodnar \& William S. Hapwood Dalam Buku System Informasi Akuntansi Penerbit ANDI Pengendalian Internal Organisasi

https://staff.blog.ui.ac.id/martani/files/2011/0 4/psak-28-revisi-20010-akuntansiasuransi-kerugian.pdf

Ikatan Akuntansi Indonesia (1991:1) Klaim 